\title{
Responsiveness of Soil Series in Southwestern Nigeria to Single Super Phosphate Fertilization
}

\author{
Mercy O. Anetor ${ }^{1}$, John A. I. Omueti ${ }^{1} \&$ Kolapo O. Oluwasemire ${ }^{1}$ \\ ${ }^{1}$ Department of Agronomy, University of Ibadan, Ibadan, Nigeria \\ Correspondence: Mercy O. Anetor, Department of Agronomy, University of Ibadan, Ibadan, Nigeria. E-mail: \\ mercy2178@yahoo.com
}

Received: September 29, 2014 Accepted: October 24, 2014 Online Published: December 15, 2014

doi:10.5539/jas.v7n1p78 URL: http://dx.doi.org/10.5539/jas.v7n1p78

\begin{abstract}
Application of Single Super Phosphate (SSP) fertilizer in soils with inadequate phosphorus (P) should elicit crop response. However, there is an indication of inconsistent response behaviour to SSP fertilizer in some Nigeria soils despite their low available P. This study identified major soil types in Southwestern Nigeria that are unresponsive to $\mathrm{P}$ fertilizer application under screenhouse condition and soil properties that are related to this unresponsive behaviour were determined. Soils from twenty locations in Southwestern Nigeria were selected to evaluate their response to four phosphorus fertilizer rates with a control replicated three times in a factorial arrangement laid out in randomized complete block design. Results indicated that most of the locations responded to initial $\mathrm{P}$ application except for Fashola 2 which produced significantly higher maize shoot yield in control soils. There were five other locations where no-response was observed. Multiple regression analysis showed that phosphorus sorption index was related to sand, organic matter and clay. Phosphorus accumulation in soil P reserves may explain the behaviour of the P-unresponsive soils irrespective of their available P levels.
\end{abstract}

Keywords: available phosphorus, maize response, sorption, soil properties

\section{Introduction}

Increasing demand for food crop production for the ever rising human population still remains a challenge of modern agriculture. However, external $\mathrm{P}$ application remains a key to sustainable production under tropical conditions (Iyamuremye et al., 1996; Zhenoy \& Kalagudi, 2005). Studies have shown that many Nigeria soils have available phosphorus (P) levels below critical level of $\leq 8 \mathrm{mg} \mathrm{kg}^{-1}$ and hence require $\mathrm{P}$ fertilizer application (Agbenin, 2003; Egwu et al., 2010). However, soils with high available P levels are mainly associated with high soil organic matter due to cropping system and management practices (Potarzycki et al., 2004). The application of P fertilizer has been shown to have tremendous effect on the soils especially the highly weathered tropical soils (Brady \& Weil, 2008). FAO (2008) has reported significant crop response with application of native phosphorus fertilizer from rock phosphate in acid soils. Similarly, the use of Single Super Phosphate (SSP) has also produced significant crop response albeit with cases of inconsistent response (Njoku \& Enwezor, 1988). Response to $\mathrm{P}$ fertiliser and ultimately maize yield are dependent on factors that influence plant growth such as soil. Different soils based on the variation in their physicochemical properties (Federal Fertilizer Department Agriculture [FFDA], 2012) lead to different crop response potentials. Differential soil responses are largely due to inherent soil characteristics, P forms and management practices (Valizadeh et al., 2002), hence, fertiliser recommendations should be designed to take cognizance of sorption characteristics of the soil.

Although, quite a number of information has been documented on responses to $\mathrm{P}$ in major food crops in Africa (Cottenie, 1981; Njoku \& Enwezor, 1988; Okalebo et al., 1996; FAO, 2008), responses observed in Nigeria were attributed to cropping season, soil heterogeneity, and crop residue removal after clearing (Kang \& Osiname, 1979). In some Southeastern Nigeria soils (Osodeke et al., 2004), no response to $P$ was attributed to high soil $P$ levels in the locations studied while other locations with low soil $\mathrm{P}$ content, required unusually higher $\mathrm{P}$ application rates to elicit response to P fertilizer (Enwezor, 1977). Similarly, pockets of soils with inconsistent soil behaviour have been observed in some Western Nigeria savanna and forest soils (Adepetu \& Corey, 1977; Kang \& Osiname, 1979; Ayodele, 1986).

Phosphorus-unresponsive soils may constitute an appreciable area of cropland in Nigeria and continuous $\mathrm{P}$ application in soils will reduce the efficient use of $\mathrm{P}$ in these soils. It will also be difficult to calibrate and make 
fertiliser recommendation for this group of soils (Ayodele, 1980). Little or no study in the past has focused on identifying P-unresponsive soils and little or no attempt has been made to identify the soil properties responsible of unresponsiveness to $\mathrm{P}$ as well as the appropriate management practices. Generalization on the soil properties that influence its unresponsiveness can not best explain its unusual behaviour. Very few or no studies have taken into consideration variations in soil parent materials as well as soil characteristics. There is a possibility that, $\mathrm{P}$ released from sorption sites during cropping may influence this soil unresponsiveness. The inability of soil test extractants to measure residual $\mathrm{P}$ in these unresponsive soils and/or the presence of numerous sorption sites that exist in these soils may also contribute to soil unresponsiveness to applied $\mathrm{P}$. The lack of crop response to $\mathrm{P}$ application could also be related to geology i.e. soil parent material and soil management practices. Hence, the need to study soils representative of various locations and their parent materials, the agro-ecology and soil management practices. It is believed that soils with inconsistent behaviour constitute a considerable part of cropland in Nigeria. Hence, identifying these soils with low response potentials would elicit suggestions on how to improve $\mathrm{P}$ release and $\mathrm{P}$ uptake by crops. Information provided from this study, will also improve existing $\mathrm{P}$ calibration i.e standard soil $\mathrm{P}$ test value at which we expect response to $\mathrm{P}$ fertilizer recommendations.

The objectives of this study under screenhouse conditions using maize as a test crop are (i) to identify soils in Southwestern Nigeria that are unresponsive to P fertilizer and (ii) to determine soil properties that are related to their unresponsiveness.

\section{Materials and Methods}

\subsection{Soil Sample Collection}

A total of seventeen soil samples of different soil series (from twenty locations, belonging to a variety of parent materials, vegetation and soil management practices were collected from various locations in Lagos, Oyo, Ogun, Osun, Edo and Ondo states of Nigeria (Table 1). Soils were sampled from farmers' fields which have been cropped for two years up to eight years, in fallows, and other ones in the national Agricultural Research Institute (ARI) fields established on coastal swamp, forest and derived savannah vegetations assembling the coastal plain sands, basement complex and sedimentary parent materials. The locations of the selected sites are shown in Figure 1. Bulk top soil $(0-20 \mathrm{~cm})$ samples were collected from 5-6 points in each location. Soil samples were air dried, sieved through $2 \mathrm{~mm}$ sieve. Composite samples were taken from the bulked soil samples for physical and chemical analysis. The bulk soil samples were labeled and stored for laboratory analysis and filling of plastic pots for screenhouse work.

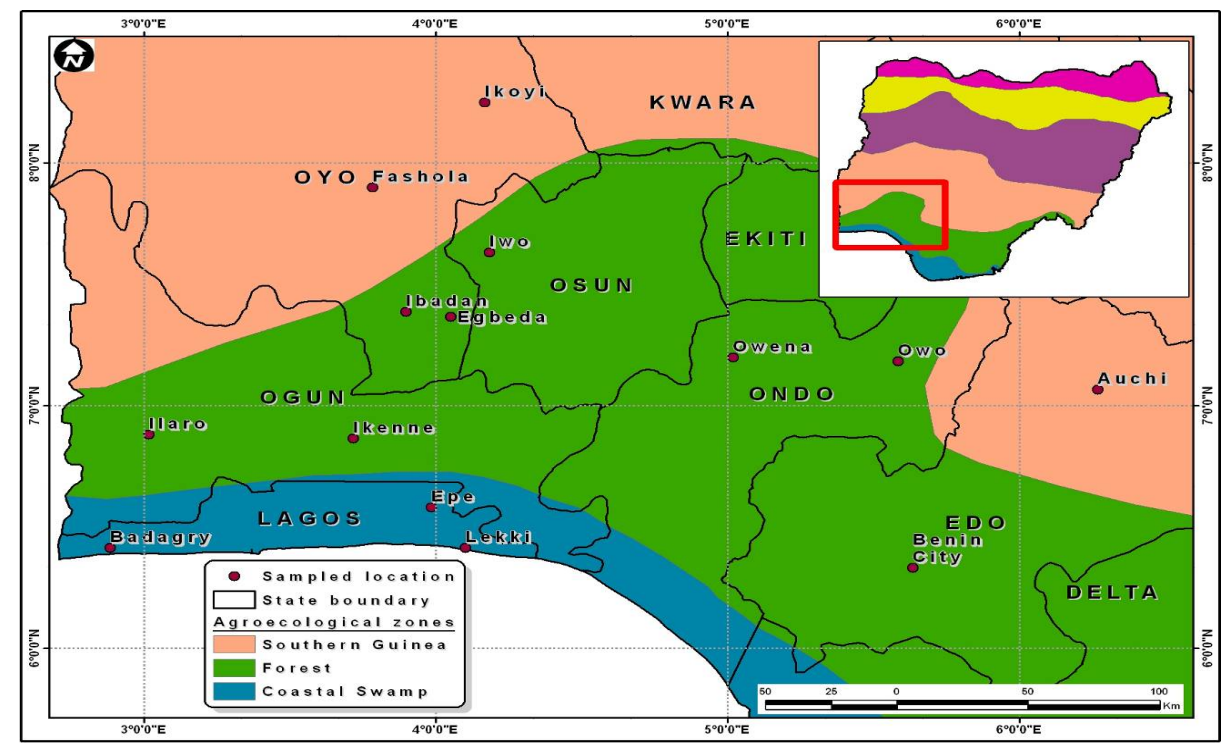

Figure 1. Locations of soils sampled

\subsection{Soil Analyses}

Soil analyses were carried out in the laboratory of the Department of Agronomy, University of Ibadan, Nigeria. Soil physical and chemical parameters were analysed as described by Udo and Ogunwale (1986) in the 
laboratory Manual for the analysis of soil, plant and water. Particle size analysis into sand, silt and clay was done using the hydrometer method. Soil $\mathrm{pH}$ was carried out on a 1:2 (soil:water) ratio after 15 minutes equilibration period using a glass electrode calibrated to buffers $\mathrm{pH} \mathrm{4,7}$ and 9. Organic carbon was determined by the dichromate wet oxidation method. Exchangeable acidity was extracted with $1 \mathrm{~N} \mathrm{KCl}$ and titrated against $0.01 \mathrm{~N}$ $\mathrm{NaOH}$. The Effective cation exchange capacity (ECEC) was obtained by summing up of the total exchangeable base (TEB) and total exchangeable acidity (TEA). Total nitrogen was determined by the Kjeldahl method. Exchangeable cations ( $\mathrm{Ca}, \mathrm{Mg}, \mathrm{K}$ and $\mathrm{Na}$ ) were extracted with $\mathrm{I} \mathrm{N} \mathrm{NH}_{4} \mathrm{OAc}(\mathrm{pH} 7)$ at a soil: extraction solution ratio of 1:10 for 15 minutes. Trace elements i.e. $\mathrm{Fe}, \mathrm{Mn}, \mathrm{Cu}$ and $\mathrm{Zn}$ were extracted with $0.1 \mathrm{~N} \mathrm{HCl}$. and quantified using Atomic Absorption Spectrophotometer (Model 210/211 and bulk scientific, USA). Bray P-1 was determined by the Molybdenum blue colour method.

\subsection{Determination of Free Fe and Al Oxides}

The extraction method with $0.2 \mathrm{M}$ ammonium oxalate acid and oxalic acid solution (Blakemore et al., 1987) was used to extract ammonium oxalate extractable iron and aluminium $\left(\mathrm{Fe}_{\mathrm{o}}\right.$ and $\mathrm{Al}_{\mathrm{o}}$.). They were quantified using inductively coupled plasma - atomic emission spectrum at 258.8 and $396.1 \mathrm{~nm}$ wavelength, respectively. Dithionite citrate bicarbonate (DCB) extraction method (Blakemore et al., 1987) was used to extract dithionite citrate bicarbonate extractable iron and aluminium $\left(\mathrm{Fe}_{\mathrm{d}}\right.$ and $\left.\mathrm{Al}_{\mathrm{d}}\right)$ in the extracts and quantification done by inductively coupled plasma - atomic emission spectrum.

\subsection{Determination of Phosphorus Sorption Index (PSI)}

Modified single point adsorption (SPA) procedure (Bauche \& Williams, 1971; Sims, 2000) was carried out to provide a quick estimate of the phosphorus sorption capacity of the soils screened and the information on the phosphorus sorption index (PSI) of the soils. Phosphorus sorption index was calculated by dividing the P sorbed with the $\log$ of $\mathrm{P}$ in the equilibrium solution as follows:

$$
\text { PSI }=\frac{P \text { sorbed }}{\log c}
$$

Where $\mathrm{c}=\mathrm{P}$ concentration at $75 \mathrm{mg} \mathrm{P}^{-1}$.

\subsection{Screenhouse Studies with Single Super Phosphate}

The rates of single super phosphate (SSP) applied per hectare were $0,30,60,90$, and $120 \mathrm{~kg} \mathrm{P}_{2} \mathrm{O}_{5}$ equivalent to $0.25,0.5,0.75$ and $1 \mathrm{~g}$ per $6 \mathrm{~cm}$-diameter plastic pot containing $3 \mathrm{~kg}$ of soil with drainage holes. Each rate was comprised of 20 plastic pots arranged in completely randomized design with three replications i.e. 60 plastic pots for the three replications. A total of three hundred experimental pots were used for all the soils. Urea was applied at the rate of $120 \mathrm{~kg} \mathrm{~N}^{-1}$ i.e. $0.37 \mathrm{~g} /$ plastic pot to supply adequate $\mathrm{N}$ to the maize crop in addition to SSP rates and thoroughly mixed with the soil. Pottasium was applied at $30 \mathrm{~kg} \mathrm{K20} \mathrm{ha-1} \mathrm{i.e} 0.06 \mathrm{~g} / \mathrm{plastic}$ pot and $\mathrm{Zn}$ was applied at $4 \mathrm{~kg} \mathrm{Zn}$ ha-1 i.e $0.75 \mathrm{ml} / \mathrm{plastic}$ pot. The experiment was a factorial laid out in randomized complete block design. The soils were sown with four maize seeds (TZE comp 3DT) after watering to field capacity $(0.53-0.80 \mathrm{~L})$. Maize plants were thinned to two seedlings, five days after sowing and subsequently grown for six weeks. The harvesting of maize shoots was done after six weeks of growth and oven dried at $65{ }^{\circ} \mathrm{C}$ until constant weight and stored in labeled envelopes. The second cropping of maize was carried out after removal of the roots from the plastic pot soil. Maize shoot dry matter, PSI and soil properties data were subsequently analyzed statistically using the analysis of variance (ANOVA) and multiple regression analysis in Genstat (Genstat version 10.3DE).

\section{Results}

\subsection{The Physical and Chemical Characteristics of the Soils Studied}

Soils were analysed prior to using them to fill the plastic pots. Results indicated that total nitrogen $(\mathrm{N})$ was below critical limit of $1.5 \mathrm{~g} \mathrm{~kg}^{-1}$. K, Ca and Mg were above FFDA's, (2012) critical limits of 0.15, 0.2, and 0.2 $\mathrm{cmol} \mathrm{kg}^{-1}$, respectively. The physical and chemical characteristics of the top soil $(0-20 \mathrm{~cm})$ are shown in Table 2 . The soil properties varied with the soil type. Soil $\mathrm{pH}\left(\mathrm{H}_{2} \mathrm{O}\right)$ ranged from 5.0 to 6.4 with an average of $5.6 \pm 0.54$ for top soil while $\mathrm{pH}(\mathrm{KCl})$ ranged from 3.7 to 5.8 with an average of $4.7 \pm 0.62$. Therefore, the soils ranged from strongly acid to slightly acid. Mean organic carbon was $19 \pm 9.6 \mathrm{~g} \mathrm{~kg}^{-1}$ ranging from 11 to $54 \mathrm{~g} \mathrm{~kg}^{-1}$ for $0-20 \mathrm{~cm}$ top soil while the total $\mathrm{N}$ varied from 0.1 to $1.26 \mathrm{~g} \mathrm{~kg}^{-1}$ with an average value of $0.47 \pm 0.3 \mathrm{~g} \mathrm{~kg}^{-1}$. The classification of exchangeable bases in the decreasing order of presence in the top soil was $\mathrm{Ca}, \mathrm{Mg}, \mathrm{K}, \mathrm{Na}$. Mean values for $\mathrm{Ca}, \mathrm{Mg}, \mathrm{K}$, and $\mathrm{Na}$ were $2.47 \pm 1.6,1.2 \pm 0.02,0.85 \pm 0.24$, and $0.2 \pm 0.02 \mathrm{cmol} \mathrm{kg}^{-1}$. 
Table 1. Land use/cover, parent materials and soil types of the sampling sites

\begin{tabular}{|c|c|c|c|c|c|}
\hline Soil No. & Site Location & Land use/cover & Soil* series & $\begin{array}{l}\text { USDA* classification } \\
\text { (Soil taxonomy) }\end{array}$ & $\begin{array}{l}\text { Parent* } \\
\text { material }\end{array}$ \\
\hline 1 & $\begin{array}{l}\text { NIFOR, Edo state } \\
06^{\circ} 33^{\prime} \mathrm{N} ; 005^{\circ} 37^{\prime} \mathrm{E}\end{array}$ & $\begin{array}{l}\text { Oil palm garden; coconut } \\
\text { plantation. }\end{array}$ & $\begin{array}{l}\text { Alagba } \\
\text { NIFOR }\end{array}$ & Typic paleudult & $\begin{array}{c}\text { Coastal } \\
\text { plain sands }\end{array}$ \\
\hline 2 & $\begin{array}{l}\text { NIFOR, Edo state } \\
06^{\circ} 34^{\prime} \mathrm{N} ; 005^{\circ} 37^{\prime} \mathrm{E}\end{array}$ & Coconut plantation. & $\begin{array}{l}\text { Ahiara } \\
\text { NIFOR }\end{array}$ & Typic paleudult & $\begin{array}{c}\text { Coastal } \\
\text { plain sands }\end{array}$ \\
\hline 3 & $\begin{array}{c}\text { Fashola Farm Settlement, } \\
\text { Fashola, Oyo state } \\
7^{\circ} 54^{\prime} \mathrm{N} ; 3^{\circ} 47^{\prime} \mathrm{E}\end{array}$ & $\begin{array}{l}\text { Bush re-growth for } 2 \text { years } \\
\text { Formerly grown are cassava and } \\
\text { maize. No fertilizer use. }\end{array}$ & Fashola & Typic kanhaplustalf & $\begin{array}{l}\text { Basement } \\
\text { complex }\end{array}$ \\
\hline 4 & $\begin{array}{c}\text { Ibodo/Ikoyi village, Oyo state } \\
8^{\circ} 17^{\prime} \mathrm{N} ; 4^{\circ} 12^{\prime} \mathrm{E}\end{array}$ & $\begin{array}{l}\text { Cashew plantation. Crops grown } \\
\text { over } 20 \text { years are cassava, } \\
\text { pepper, tomatoes, cashew and } \\
\text { orange. NPK fertiliser used. }\end{array}$ & Shante & Typic ustipsamment & $\begin{array}{l}\text { Basement } \\
\text { complex }\end{array}$ \\
\hline 5 & $\begin{array}{l}\text { Lahan village through Iwo town, } \\
\text { Osun state } \\
7^{\circ} 42^{\prime} \mathrm{N} ; 4^{\circ} 12^{\prime} \mathrm{E}\end{array}$ & $\begin{array}{l}\text { Cassava + maize intercrop in } \\
\text { addition to okra, yam and maize } \\
\text { crops grown. No inorganic } \\
\text { fertiliser use for } 4 \text { years but } \\
\text { organic manure has been used. }\end{array}$ & Iwo & Typic paleustalf & $\begin{array}{l}\text { Basement } \\
\text { complex }\end{array}$ \\
\hline 6 & $\begin{array}{l}\text { Auchi, Edo state } \\
32^{\circ} 96^{\prime} \mathrm{N} ; 07^{\circ} 83^{\prime} \mathrm{E}\end{array}$ & $\begin{array}{l}\text { Cassava }+ \text { maize mixture mainly } \\
\text { grown. }\end{array}$ & Ahiara & Typic paleustult & $\begin{array}{c}\text { Coastal } \\
\text { plain sands }\end{array}$ \\
\hline 7 & $\begin{array}{l}\text { Fashola, Oyo state } \\
7^{\circ} 54^{\prime} \mathrm{N} ; 3^{\circ} 47^{\prime} \mathrm{E}\end{array}$ & $\begin{array}{l}\text { Bush re-growth for } 2 \text { years. } \\
\text { Cassava }+ \text { maize intercrop } \\
\text { grown. NPK fertiliser } \\
\text { commonly used. }\end{array}$ & Оуо & Typic kanhaplustalf & $\begin{array}{l}\text { Basement } \\
\text { complex }\end{array}$ \\
\hline 8 & $\begin{array}{l}\text { Lahan village through Iwo town, } \\
\text { Osun state } \\
7^{\circ} 42^{\prime} \mathrm{N} ; 4^{\circ} 12^{\prime} \mathrm{E}\end{array}$ & $\begin{array}{l}\text { Cassava +maize intercrop okra, } \\
\text { yam and maize. No inorganic } \\
\text { fertiliser use for } 4 \text { years but } \\
\text { organic manure has been used. }\end{array}$ & Ibadan & Typic paleustalf & $\begin{array}{c}\text { Basement } \\
\text { complex }\end{array}$ \\
\hline 9 & $\begin{array}{l}\text { Ogun state farm settlement, } \\
\text { Ikenne, Ogun state } \\
6^{\circ} 50^{\prime} \mathrm{N} ; 3^{\circ} 41^{\prime} \mathrm{E}\end{array}$ & $\begin{array}{l}\text { Main crops grown is maize. Soil } \\
\text { management with NPK/Urea. }\end{array}$ & Alagba & Udic Haplorthox & Sand stone \\
\hline
\end{tabular}

Source: *Moss (1957); Smyth and Montgomery (1962); Murdoch et al. (1976).

Table 1. Continued

\begin{tabular}{|c|c|c|c|c|c|}
\hline Soil No. & Site Location & Land use/cover & Soil* series & $\begin{array}{l}\text { USDA* classification } \\
\text { (Soil taxonomy) }\end{array}$ & $\begin{array}{l}\text { Parent* } \\
\text { material }\end{array}$ \\
\hline 10 & $\begin{array}{c}\text { Ogun state farm settlement, } \\
\text { Ikenne } \\
6^{\circ} 50^{\prime} \mathrm{N} ; 3^{\circ} 41^{\prime} \mathrm{E}\end{array}$ & $\begin{array}{l}\text { Main crops grown are maize. Soil } \\
\text { management with NPK/Urea. }\end{array}$ & Agege & Typic Eustrustox & sandstone \\
\hline 11 & $\begin{array}{c}\text { Ogbese through Owo, Ondo state } \\
7^{\circ} 18.27^{\prime} \mathrm{N} ; 5^{\circ} 20.15^{\prime} \mathrm{E}\end{array}$ & Cocoa plantation. & Owo & Oxic Tropulstalf & $\begin{array}{l}\text { Basement } \\
\text { complex }\end{array}$ \\
\hline 12 & $\begin{array}{c}\text { Ilaro, Ogun state } \\
6^{\circ} 53.246^{\prime} \mathrm{N} ; 3^{\circ} 08.005^{\prime} \mathrm{E}\end{array}$ & $\begin{array}{l}\text { cassava }+ \text { maize }+ \text { pepper intercrop } \\
\text { on heaps. Fertiliser commonly } \\
\text { used is Urea fertilizer. }\end{array}$ & Ilaro & Oxic paleustalf & sandstone \\
\hline 13 & $\begin{array}{c}\text { Owena Ijesha, Osun state } \\
7^{\circ} 24^{\prime} \mathrm{N} ; 5^{\circ} 02^{\prime} \mathrm{E}\end{array}$ & Cocoa plantation/ cocoyam. & Itagunmodi & Rhodustalf & $\begin{array}{c}\text { Basement } \\
\text { complex }\end{array}$ \\
\hline 14 & $\begin{array}{l}\text { Ogbese through Owo, Ondo state } \\
\qquad 7^{\circ} 16^{\prime} \mathrm{N} ; 5^{\circ} 20^{\prime} \mathrm{E}\end{array}$ & $\begin{array}{l}\text { Cocoa plantation (over } 20 \text { years } \\
\text { old). }\end{array}$ & Ondo & Oxic Tropustalf & $\begin{array}{l}\text { Basement } \\
\text { complex }\end{array}$ \\
\hline 15 & $\begin{array}{c}\text { Owena Ijesha, Osun state } \\
7^{\circ} 24^{\prime} \mathrm{N} ; 5^{\circ} 02^{\prime} \mathrm{E}\end{array}$ & Cocoa and coco yam. & Owena & Rhodustalfs & $\begin{array}{l}\text { Basement } \\
\text { complex }\end{array}$ \\
\hline 16 & $\begin{array}{l}\text { IAR\&T Ikenne } \\
6^{\circ} 50^{\prime} \mathrm{N} ; 3^{\circ} 41^{\prime} \mathrm{E}\end{array}$ & Fallow land for over 10 years. & Owode & Oxic Haplustult & sandstone \\
\hline
\end{tabular}




\begin{tabular}{|c|c|c|c|c|c|}
\hline 17 & $\begin{array}{l}\text { Badagry,Lagos state } \\
\quad 6^{\circ} 25^{\prime} \mathrm{N} ; 3^{\circ} 02^{\prime} \mathrm{E}\end{array}$ & Forest. & Iweke & Aquic Tropaquept & $\begin{array}{c}\text { Coastal } \\
\text { plain sand }\end{array}$ \\
\hline 18 & $\begin{array}{l}\text { Egbeda, Oyo state } \\
07.22^{\prime} \mathrm{N} ; 004.02^{\prime} \mathrm{E}\end{array}$ & $\begin{array}{l}\text { Fallow not maintained. Grown to } \\
\text { mango, oranges, kola nuts. }\end{array}$ & Egbeda & tropaquept & $\begin{array}{l}\text { Basement } \\
\text { complex }\end{array}$ \\
\hline 19 & $\begin{array}{l}\text { Egbeda, Oyo state } \\
07.22 \mathrm{~N} ; 004.02 \mathrm{E}\end{array}$ & $\begin{array}{l}\text { Bush regrowth for about } 2 \text { years. } \\
\text { Mainly grown with cassava }+ \\
\text { maize intercrop. }\end{array}$ & Olorunda & Rhodustalfs & $\begin{array}{l}\text { Basement } \\
\text { complex }\end{array}$ \\
\hline 20 & $\begin{array}{l}\text { Epe, Lagos state } \\
07.22 \mathrm{~N} ; 004.02\end{array}$ & $\begin{array}{l}\text { Crops grown are maize, pineapple, } \\
\text { cassava on the flat. Presence of } \\
\text { cashew tree noticed. NPK } \\
\text { fertiliser used. cassava + maize } \\
\text { intercrop. }\end{array}$ & Iweke & Aquic Tropaquept & $\begin{array}{c}\text { Coastal } \\
\text { plain sand }\end{array}$ \\
\hline
\end{tabular}

Source: *Moss (1957); Smyth and Montgomery (1962); Murdoch et al. (1976).

Table 2. Physical and chemical properties of the top soils $(0-20 \mathrm{~cm})$

\begin{tabular}{|c|c|c|c|c|c|c|c|c|c|c|c|c|c|c|c|}
\hline \multirow{2}{*}{$\begin{array}{l}\text { Soil } \\
\text { Location }\end{array}$} & \multirow{2}{*}{ Soil series } & \multirow[t]{2}{*}{ Sand } & \multirow{2}{*}{$\begin{array}{c}\text { Silt } \\
\%\end{array}$} & \multirow[t]{2}{*}{ Clay } & \multirow{2}{*}{$\begin{array}{c}\text { Textural Class } \\
\text { (USDA) }\end{array}$} & \multirow{2}{*}{$\begin{array}{l}\mathrm{pH} \\
\left(\mathrm{H}_{2} \mathrm{O}\right)\end{array}$} & \multirow{2}{*}{$\begin{array}{l}\mathrm{pH} \\
(\mathrm{KCl})\end{array}$} & $\mathrm{OC}$ & Total N & $\mathrm{Ca}$ & $\mathrm{Mg}$ & $\mathrm{K}$ & $\mathrm{Na}$ & \multirow{2}{*}{$\begin{array}{l}\text { Exch } \\
\text { acidity }\end{array}$} & \multirow{2}{*}{ ECEC } \\
\hline & & & & & & & & & $\mathrm{kg}^{-1}$ & \multicolumn{4}{|c|}{$\mathrm{cmol} \mathrm{kg}^{-1}$} & & \\
\hline NIFOR 1 & $\begin{array}{l}\text { Alagba } \\
\text { NIFOR }\end{array}$ & 89.2 & 3.4 & 7.4 & sand & 5.0 & 3.7 & 18 & 1.26 & 1.1 & 0.9 & 1.7 & 0.2 & 1.0 & 4.9 \\
\hline NIFOR 2 & $\begin{array}{l}\text { Ahiara } \\
\text { NIFOR }\end{array}$ & 91.2 & 3.4 & 5.4 & sand & 5.3 & 4.3 & 20 & 0.80 & 1.7 & 1.2 & 1.6 & 0.3 & 0.6 & 5.4 \\
\hline Fashola 1 & Fashola & 85.2 & 7.4 & 7.4 & Sand & 5.4 & 4.4 & 18 & 0.38 & 0.4 & 0.7 & 1.8 & 0.2 & 0.2 & 3.3 \\
\hline Fashola 2 & Oyo & 89.2 & 5.4 & 5.4 & sand & 5.8 & 4.9 & 21 & 0.24 & 1.9 & 0.6 & 1.5 & 0.2 & 0.6 & 4.8 \\
\hline Ikoyi & Shante & 79.2 & 11.4 & 9.4 & Loamy Sand & 5.8 & 4,8 & 14 & 0.49 & 0.9 & 0.7 & 1.5 & 0.2 & 0.6 & 3.9 \\
\hline Iwo 1 & Iwo & 79.2 & 11.4 & 9.4 & Loamy Sand & 5.6 & 4.6 & 22 & 0.42 & 1.2 & 0.7 & 1.6 & 0.1 & 0.6 & 4.2 \\
\hline Iwo 2 & Ibadan & 85.2 & 9.4 & 5.4 & Loamy Sand & 6.2 & 5.0 & 20 & 0.10 & 2.1 & 0.7 & 1.7 & 0.2 & 0.4 & 5.1 \\
\hline Auchi & Ahiara & 85.2 & 7.4 & 7.4 & Sand & 5.8 & 5.1 & 10 & 0.21 & 1.4 & 0.8 & 1.8 & 0.2 & 0.2 & 4.4 \\
\hline Ikenne 1 & Alagba & 87.2 & 5.4 & 7.4 & Loamy Sand & 5.8 & 5.0 & 6 & 0.38 & 2.4 & 0.8 & 1.8 & 0.2 & 0.4 & 5.6 \\
\hline Ikenne 2 & Agege & 83.2 & 9.4 & 7.4 & Loamy Sand & 5.2 & 4.4 & 20 & 0.28 & 3.3 & 0.8 & 1.8 & 0.2 & 0.6 & 6.7 \\
\hline Ikenne 3 & Owode & 69.2 & 19.4 & 11.4 & Sandy Loam & 5.7 & 4.7 & 17 & 0.28 & 4.1 & 0.6 & 1.5 & 0.2 & 0.2 & 6.6 \\
\hline Ilaro & Ilaro & 73.2 & 13.4 & 13.4 & Sandy Loam & 6.4 & 5.4 & 10 & 0.42 & 1.7 & 0.7 & 1.6 & 0.2 & 0.6 & 4.8 \\
\hline Owo 1 & Owo & 73.2 & 13.4 & 13.4 & Sandy Loam & 6.0 & 5.1 & 19 & 0.42 & 4.4 & 0.7 & 1.7 & 0.2 & 0.4 & 7.4 \\
\hline Owo 2 & Ondo & 69.2 & 15.4 & 15.4 & Sandy Loam & 6.4 & 5.8 & 54 & 0.17 & 1.8 & 0.8 & 1.9 & 0.2 & 0.2 & 4.9 \\
\hline Owena 1 & Itagunmodi & 93.2 & 3.4 & 3.4 & Sand & 5.4 & 4.8 & 17 & 0.28 & 6.0 & 1.0 & 1.5 & 0.2 & 0.4 & 9.1 \\
\hline Owena 2 & Owena & 75.2 & 15.4 & 11.4 & Sandy Loam & 6.0 & 5.1 & 11 & 0.28 & 3.2 & 0.7 & 1.8 & 0.2 & 0.2 & 6.1 \\
\hline Badagry & Iweke & 83.2 & 7.4 & 9.4 & Loamy Sand & 5.1 & 3.4 & 15 & 0.21 & 1.7 & 1.1 & 1.5 & 0.2 & 1.4 & 5.9 \\
\hline Egbeda 1 & Egbeda & 74.6 & 11.4 & 14.0 & Sandy Loam & 5.7 & 4.9 & 21 & 0.84 & 5.8 & 1.4 & 1.0 & 0.2 & 0.4 & 8.8 \\
\hline Egbeda 2 & Olorunda & 72.6 & 11.4 & 16.0 & Sandy Loam & 6.1 & 5.1 & 25 & 1.04 & 3.5 & 1.3 & 1.3 & 0.2 & 0.4 & 6.7 \\
\hline Epe & Iweke & 92.0 & 4.0 & 4.0 & Sand & 4.1 & 3.4 & 28 & 0.98 & 0.9 & 1.0 & 1.4 & 0.2 & 1.4 & 4.9 \\
\hline
\end{tabular}

The ECEC ranged from 3.3 to $9.1 \mathrm{cmol} \mathrm{kg}^{-1}$ (mean $=5.6 \pm 1.5 \mathrm{cmol} \mathrm{kg}^{-1}$ ) and the total exchangeable acidity from 0.2 to $1.4 \mathrm{cmol} \mathrm{kg}^{-1}$ (mean $=0.54$ ) for $0-20 \mathrm{~cm}$ top soil. The sand fraction was dominant in all soils and had a mean value of $81.5 \pm 7.8 \%$ with a range of 69.2 to $92.0 \%$. The silt fraction ranged from 3.4 to $19.4 \%$ with a mean of $9.3 \pm 4.5 \%$ while the clay fraction had a mean value of $9.2 \pm 3.8 \%$ and the corresponding range values of 4.0 to $15.4 \%$. The soils were broadly of sand, loamy sand and sandy loam textures.

\subsection{Phosphorus Sorption Index and Soil Properties}

Table 3 shows the values for PSI and some soil properties. The PSI values ranged from 43 to $80 \%$ with an average value of $61 \%$. According to Patterson (2003) classification, PSI values $<10 \%$ were considered very low, 
10 to $30 \%$ as low, 30 to $60 \%$ as medium, 60 to $90 \%$ as high and $>90 \%$ as very high. When this classification was adopted for the soils studied, 50\% of them (Ikenne 1, Ikenne 2, Owo 1, Owena 1, Owo 2, Owena 2, Ikenne 3 , Badagry, Egbeda 1 and Egbeda 2) fell into the medium P retention class while the other 50\% (NIFOR 1, NIFOR 2, Fashola 1, Ikoyi, Iwo 1, Auchi, Fashola 2, Iwo 2, Ilaro and Epe) fell into the high P retention class. With the exception of Fashola 2, Ikenne 2 and Badagry, the available P level in the soils was below critical level of $8 \mathrm{mg}$ $\mathrm{kg}^{-1}$.

Table 3. Phosphorus sorption index (PSI) and some soil properties of the top soils screened for unresponsiveness to phosphorus

\begin{tabular}{|c|c|c|c|c|c|c|}
\hline \multirow{2}{*}{ Soil } & \multirow{2}{*}{$\begin{array}{l}\text { PSI } \\
(\%)\end{array}$} & \multirow{2}{*}{$\begin{array}{l}\text { Bray P-1 } \\
\mathrm{mg} \mathrm{kg}^{-1}\end{array}$} & $\mathrm{Fe}_{\mathrm{d}}$ & $\mathrm{Al}_{\mathrm{d}}$ & $\mathrm{Fe}_{\mathrm{o}}$ & $\mathrm{Al}_{\mathrm{O}}$ \\
\hline & & & \multicolumn{4}{|c|}{$\mathrm{g} \mathrm{kg}^{-1}$} \\
\hline N1FOR 1 & 73 & 5.0 & 15.9 & 1.5 & 0.5 & 0.5 \\
\hline NIFOR 2 & 68 & 6.0 & 5.8 & 1.2 & 0.8 & 0.4 \\
\hline Fashola 1 & 63 & 2.0 & 16.2 & 1.0 & 0.5 & 0.5 \\
\hline Fashola 2 & 80 & 10.0 & 3.6 & 0.5 & 0.3 & 0.3 \\
\hline Ikoyi & 72 & 1.0 & 12.6 & 1.5 & 0.6 & 0.4 \\
\hline Iwo 1 & 65 & 3.0 & 9.22 & 1.5 & 0.6 & 0.8 \\
\hline Iwo 2 & 72 & 3.0 & 7.4 & 1.1 & 0.3 & 0.4 \\
\hline Auchi & 73 & 3.0 & 5.6 & 0.6 & 0.2 & 0.4 \\
\hline Ikenne 1 & 55 & 3.0 & 22.5 & 2.3 & 0.9 & 0.9 \\
\hline Ikenne 2 & 54 & 20.0 & 6.5 & 1.1 & 0.9 & 1.3 \\
\hline Ikenne 3 & 43 & 2.0 & 18.4 & 2.8 & 0.8 & 1.1 \\
\hline Ilaro & 68 & 2.0 & 4.4 & 0.7 & 0.3 & 0.4 \\
\hline Owo 1 & 59 & 3.0 & 13.8 & 1.8 & 0.5 & 0.7 \\
\hline Owo 2 & 57 & 3.0 & 36.5 & 5.5 & 0.7 & 0.9 \\
\hline Owena 1 & 51 & 1.0 & 26.8 & 4.0 & 1.1 & 1.0 \\
\hline Owena 2 & 52 & 1.0 & 18.2 & 2.7 & 0.8 & 0.7 \\
\hline Badagry & 42 & 22.0 & 23.0 & 0.6 & 1.0 & 1.7 \\
\hline Egbeda 1 & 53 & 3.0 & 22.1 & 3.1 & 0.9 & 1.4 \\
\hline Egbeda 2 & 59 & 4.0 & 24.4 & 3.0 & 1.0 & 0.9 \\
\hline Epe & 62 & 6.0 & 1.3 & 0.9 & 0.9 & 1.2 \\
\hline SED & 3.75 & 0.21 & 0.03 & 0.15 & 0.01 & 0.01 \\
\hline
\end{tabular}

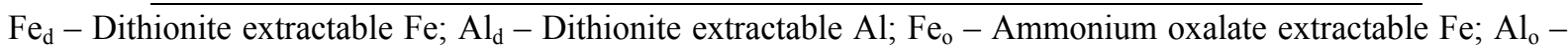
Ammonium oxalate extractable Al; SED - Standard Error of difference of Mean.

\subsection{Correlation between PSI and Some Soil Properties}

PSI was negatively correlated $(-0.77,-0.84,-0.60, \mathrm{p} \leq 0.05)$ with $\mathrm{Fe}_{\mathrm{o}}, \mathrm{Al}_{\mathrm{o}}$ and $\mathrm{Fe}_{\mathrm{d}}$ respectively, but positively correlated (sand $0.60, \mathrm{p} \leq 0.05$ ) with sand in the top soil.

\subsection{Screenhouse Experiments}

Figure 2 and 3 shows maize response to SSP in the first cropping. Significant difference was obtained in maize shoot dry matter response to $P$ levels $x$ soil types interaction $(p<=0.001, p=0.001$ respectively). Except with no $\mathrm{P}$ application, maize shoot dry matter in the first cropping was generally higher than the second. At both croppings, Egbeda 2 soil produced the highest maize shoot dry matter with no P application while the lowest shoot dry matter was obtained at NIFOR 1 soil in the first crop and Ikoyi soil in the second. Maize plants of the first crop with $30 \mathrm{~kg} \mathrm{P}_{2} \mathrm{O}_{5} \mathrm{ha}^{-1}$, produced the lowest in Owena 2 soil while Iwo 1 had the highest. However, in the second maize crop, Fashola 2 produced the lowest while Egbeda 2 had the highest. Maize plants with SSP 
application of 60, 90 and $120 \mathrm{~kg} \mathrm{P}_{2} \mathrm{O}_{5} \mathrm{ha}^{-1}$, produced the lowest and highest maize shoot dry matter in the second maize crop at Ikoyi and Egbeda 2 soils, respectively. Controls or soils which didn't receive SSP produced significantly higher maize shoot dry matter comparable to higher phosphorus of 30 to $90 \mathrm{~kg} \mathrm{P}_{2} \mathrm{O}_{5}$ ha $^{-1}$ at Fashola 2 and Ikenne 2 soils in the first crop and in Fashola 2, Iwo 2, Ikenne 1, Owo 2 and Egbeda soils in the second maize crop. Owena 1 and Owena 2 soils with $120 \mathrm{~kg} \mathrm{P}_{2} \mathrm{O}_{5}$ ha $^{-1}$ produced significantly higher maize shoot dry matter in the first cropping however, it was not significantly different from 60 and $90 \mathrm{~kg} \mathrm{P}_{2} \mathrm{O}_{5}$ ha $^{-1}$ for Owena 1 soil and $90 \mathrm{~kg} \mathrm{P}_{2} \mathrm{O}_{5}$ ha $^{-1}$ for Owena 2 soil in the second cropping. Based on the PSI of $51 \%$ and $52 \%$, moderate $\mathrm{P}$ application may be required for Owena 1 and Owena 2 soils. NIFOR 1, NIFOR 2, Fashola 1, Fashola 2, Ikoyi, Iwo 1, Iwo 2, Auchi, Ilaro and Epe soils with PSI levels between $60-90 \%$, may require high P application. However, with Egbeda 1 soil, significantly higher maize shoot dry matter was obtained from $120 \mathrm{~kg} \mathrm{P}_{2} \mathrm{O}_{5} \mathrm{ha}^{-1}$ in the first cropping while $30 \mathrm{~kg} \mathrm{P}_{2} \mathrm{O}_{5} \mathrm{ha}^{-1}$ produced significant higher maize shoot dry matter in the second cropping.

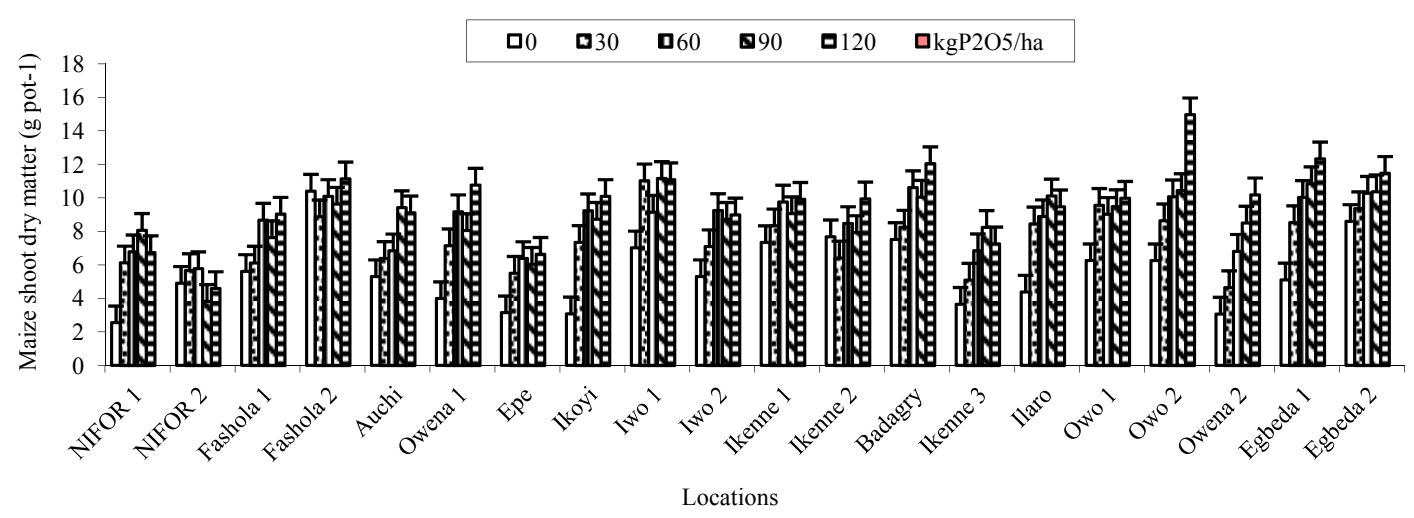

Figure 2. Effects of different levels of phosphorus on maize shoot dry matter of twenty different locations under screenhouse conditions for first cropping (Extensions on bars represent SED AT P $<0.05$ )

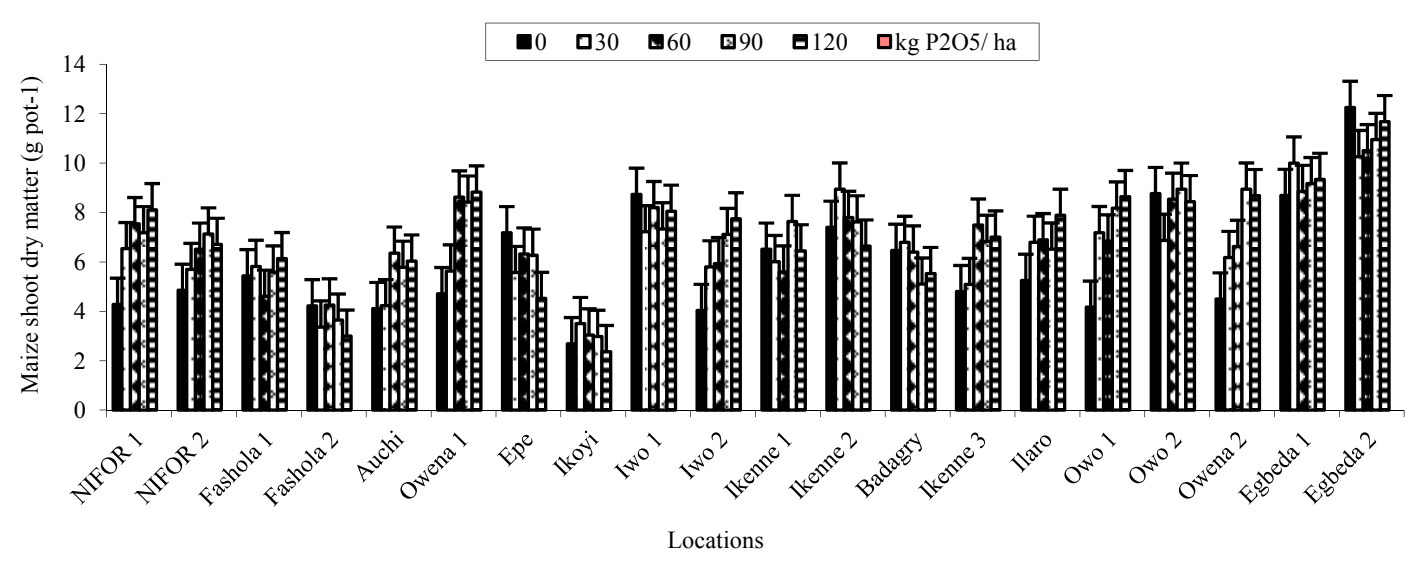

Figure 3. Effects of different levels of phosphorus on maize shoot dry matter of twenty different locations under screenhouse conditions for second cropping (Extensions on bars represent SED AT P $<0.05$ )

\section{Discussion}

The high maize shoot dry matter in response to $120 \mathrm{~kg} \mathrm{P}_{2} \mathrm{O}_{5}$ ha $^{-1}$ observed at Egbeda 1 soil in the first cropping (Egbeda soil series) is in line with the result of Kang and Osiname (1979) whose top soil texture appears to be the same with the soil in this study. Even though national fertilizer recommendation for low $\mathrm{P}$ soils in Nigeria is $60 \mathrm{~kg} \mathrm{P}_{2} \mathrm{O}_{5} \mathrm{ha}^{-1}$ (FFDA, 2012), Egbeda soil series may require high $\mathrm{P}$ application to build up and maintain available P levels of $14 \mathrm{mg} \mathrm{P} \mathrm{kg}^{-1}$ (Kang \& Osiname, 1979). However, there is need for caution in applying $\mathrm{P}$ fertilizer in Egbeda soil based on the PSI (53\%) and the residual P effect obtained at $30 \mathrm{~kg} \mathrm{P}_{2} \mathrm{O}_{5} \mathrm{ha}^{-1}$. Using the maize shoot dry matter production as a criterion for selecting P-unresponsive soils, higher maize shoot dry 
matter from control soils over soils with $\mathrm{P}$ applications was considered as P-unresponsive and this formed the basis for identifying P-unresponsive soils. From the first cropping, it was observed that NIFOR 2, Fashola 2 and Ikenne 2 soil produced higher maize shoot dry matter over control soil. Fashola 2 and NIFOR 2 soils had moderate P levels (Cottenie, 1980; FFDA, 2012). The high maize shoot dry matter from soils with no SSP addition for Fashola 2 confirms previous observation of a lack of $\mathrm{P}$ response in Fashola soils by Sanginga et al. (1995) and Sanginga et al. (2000). Higher maize shoot dry matter from soils with zero SSP application compared with lower maize shoot dry matters from soils where SSP was applied was also observed at Epe soil with predominant sand texture in the second cropping (Brady \& Weil, 2008). Previous study (Adepetu \& Corey, 1977) has indicated no P response at Iwo 1 soil (Iwo soil series).

Three of the selected P-unresponsive soils (Fashola 2, Owo 2 and Egbeda 2) are major agricultural soils derived from basement complex parent materials which are very variable in soil physical and chemical properties. Ikenne 1 and Ikenne 2 soils are derived from sedimentary parent material which is moderately variable, while NIFOR 2 soil derived from coastal plain sands parent material is least variable. The six selected P-unresponsive soils fell into the medium and high P retention class. Four of the six selected P-unresponsive soils produced higher maize shoot dry matter in the residual cropping. This may suggest that residual/sorbed $\mathrm{P}$ may influence P-unresponsiveness.

There was positive and significant relationship between $\mathrm{P}$ sorbed and sand particles. Free Fe oxides can exist as coatings on sand soils (Bolland et al., 1996) and as such P was not directly sorbed onto Fe and Al oxide in the soils of this study. Earlier studies by Ojanuga et al. (1975) and Uyovbisere and Chude (1995) have also reported negative relationship between sorption parameters and free Fe oxides in some Nigerian soils. The multiple regression equation relating percent PSI to soil parameters is given as:

PSI $(\%)=-42.9+$ Sand $(0.1207)+$ organic matter $(0.288)+$ clay $(0.1712)$.

Multiple regression analysis performed to look for the correlation between soil properties and phosphorus sorption index indicated that sand fraction, organic matter and clay content were the most associated variables. $\left(\mathrm{R}^{2}=0.88, \mathrm{p}=0.001\right)$ The relative contribution of the soil variables were sand $(31 \%)$, organic matter $(28 \%)$, clay $(27 \%)$, Bray P-1 $(8 \%)$ and $\mathrm{pH}\left(\mathrm{H}_{2} \mathrm{O}\right)(5 \%)$. Criteria used was based on the $\mathrm{F}$ probability of each individual variable (soil properties) added to the model. This study ranked clay as third contributor to P sorption unlike that of Axt \& Walbridge (1999) who identified clay and silt as best predictors of PSI using stepwise regression for some upland soils.

\section{Conclusion}

These selected P-unresponsive soils may have $\mathrm{P}$ accumulation in soil $\mathrm{P}$ sorption sites that is made available in the residual cropping. Thus, residual/sorbed $\mathrm{P}$ may influence the response potentials of these soils irrespective of their native available P levels. Efforts to improve P availability in these soils can either mask P deficiency or accumulate P and consequently, produce irregular response to P. For NIFOR 2, Fashola 2, Ikenne 1, Ikenne 2, , Owo 2, and Egbeda 2 where inconsistent and no response to $\mathrm{P}$ fertilizer was observed, there is need for detailed study of the chemistry of these P-unresponsive soils.

\section{Acknowledgements}

The authors gratefully acknowledge the support of International Foundation for Science (IFS), the University of Ibadan Scholarship award and the TWAS-CAS Fellowship. This report is a part of the Ph.D thesis of Mercy O. Anetor in the Postgraduate School, University of Ibadan.

\section{References}

Adepetu, J. A., \& Corey, R. B. (1977). Changes in nitrogen and phosphorus availability and phosphorus fractions in Iwo soil from Nigeria under intensive cultivation. Plant and Soil, 46, 309-316. http://dx.doi.org/10.1007/BF00010087

Agbenin, J. O. (2003). Extractable iron and aluminium effects on phosphate sorption in a savanna Alfisol. Soil Science Society of America Journal, 67, 589-595. http://dx.doi.org/10.2136/sssaj2003.0589

Anne, J. B., \& Lal, R. (1997). Agricultural productivity in the tropics and critical limits of properties of oxisols and alfisols. Tropical Agriculture (Trinidad), 74, 96-103.

Axt, J. R., \& Walbridge, M. R. (1999). Phosphate removal capacity of Palustrine forested wetland an d adjacent uplands in Virginia. Soil Science Society of America Journal, 63, 1019-1031. http://dx.doi.org/10.2136/sssaj1999.6341019x

Ayodele, O. J. (1986). Phosphorus availability in savanna soils of western Nigeris. Tropical Agriculture 
(Trinidad), 63, 297-300.

Bauche, B. W., \& Williams, E. G. (1971). A phosphate sorption index for soils. Journal of Soil Science, 22, 289-301. http://dx.doi.org/10.1111/j.1365-2389.1971.tb01617.x

Blakemore, L. C., Searlesp, P. L., \& Daly, B. K. (1987). Methods for Chemical analysis of Soil. New zealand soil bureau scientific report (p. 103). New Zealand.

Bolland, M. D. A., Gilkes, R. J., Brennan, R. F., \& Allen, D. G. (1996). Comparison of savanna phosphorus sorption indices. Australian Journal of Soil Research, 34, 81-89. http://dx.doi.org/10.1071/SR9960081

Borling, K. (2003). Phosphorus sorption, accumulation and leaching effects of long term inorganic fertilization of cultivated soils. Acta Universitatis Agricultura Suecial Agraria, 428. http://dx.doi.org/10.1111/j.1747-0765.2006.00040.x

Brady, N. C., \& Weil, R. R. (2008). The Nature and Properties of Soil (14th ed., p. 545). Pearson Prentice Hall, Pearson Educational Incorporation, Upper saddle River, New Jersey.

Bray, R. H., \& Kurtz, L. T. (1945). Determination of total, organic and available phosphorus in soils. Soil Science, 59, 39-45. http://dx.doi.org/10.1097/00010694-194501000-00006

Cottenie, A. (1980). Soil and Plant testing as a basis of fertilizer recommendation FAO of the UN. Soils Bulletin, $38(2), 190$.

Egwu, G. N., Uyovbisere, E. O., \& Okunola, O. J. (2010). Phosphorus sorption isotherms and parameters estimates of soils of the Savanna, and effect of soil properties on these parameters. Electronic Journal of Environmental Agricultural and Food Chemistry, 9, 866-874.

Enwezor, W. O. (1977). Soil testing for phosphorus in some Nigerian soils: 2. Predicting responses to phosphate application for soils of Southeastern Nigerian. Soil Science, 123, 111-117. http://dx.doi.org/10.1097/00010694-197702000-00005

Federal Fertilizer Department (FFD). (2012). In V. O. Chude, C. Adeyiwola, P. Daudu \& A. Ekeoma (Eds.), Fertilizer use and management practices for crops in Nigeria (3rd ed., p. 204). Federal Ministry of Agriculture and Rural Development, Abuja.

Food and Agriculture Organization (FAO). (2008). Efficiency of Soil and fertilizer phosphorus use. Fertilizer and Plant Nutrition Bulletin (No. 18). FAO Rome.

Iyamuremye, F., Dick, R. P., \& Baham, J. (1996a). Organic amendments and phosphorus dynamics 1: Phosphorus Chemistry and Sorption. Soil Science, 161, 426-435. http://dx.doi.org/10.1097/00010694-199607000-00004

Kang, B. T., \& Osiname, O. A. (1979). Phosphorus response of maize grown on Alfisols of Southern Nigeria. Agronomy Journal, 71, 873-877. http://dx.doi.org/10.2134/agronj1979.00021962007100050039x

Mehlich, A. (1984). Mehlich 3 soil test extractant: A modification of the Mehlich 2. Communication in Soil Science and Plant Analysis, 15, 1409-1416. http://dx.doi.org/10.1080/00103628409367568

Moss, R. P. (1957). Soil survey reports Number 67 (p. 102). Reports on the classification of the soils formed over sedimentary rocks in western Nigeria. Institute of Agricultral Research and Training, University of Ife, Ibadan, Nigeria.

Murdock, G., Ojo-Atere, J., Colborne, G., Olomu, E. I., \& Odugbesan, E. M. (1976). Soils of the Western state Savanna in Nigeria (Vol. 2). Description of Basement Complex Soil Series. Land Resource Study, 23, 145.

Njoku, B. O., \& Enwezor, W. O. (1988). Differential response of four cassava cltivars (Manihot esculenta. Cranz) to liming 1. Yields. Nigeria Journal of Soil Science, 8, 81-95.

Nwoke, O. C., Vanlauwe, B., Diels, J., Sanginga, N., \& Osonubi, O. (2004). The distribution of P fractions and desorption characteristics of some soils in the moist savanna zone of West Africa. Nutrient Cycling in Agro-Ecosystem, 69, 127-141. http://dx.doi.org/10.1023/B:FRES.0000029677.09424.ef

Ojanuga, A. G., Fenster, W. E., \& Aluko, P. A. (1975). Phosphorus adsorption and fixation by some soils of South Western Nigeria. The Nigerian Agricultural Journal, 12, 52-56.

Okalebo, J. R, Gathua, K. W., \& Woomer, P. L. (1993). Laboratory methods of soil and plant analysis (p. 88) (A working manual). Soil chemistry laboratory, the Kenya Agricultural Research Institute, National Agricultural Research centre, MUGUGA, Kenya. The tropical soil biology and fertility programme, regional office for science and technology for Africa, UNESCO, Nairobi, Kenya. 
Osodeke, V. E., Nwofia, G. E., \& Atulomah, E. H. (2004). Response of Okra (Abelmoschus esculentus, L.Moench) to P fertilizer in the soils of the Forest zone of SouthEastern Nigeria. Nigeria Agricultural Journal, 35, 150-160.

Patterson, R. A. (2001). In R. A. Patterson \& M. J. Jones (Eds.), Phosphorus sorption for on-site waste water assessment in proceedings of on-site 2001 conference: Advancing on-site waste water systems (pp. 307-314). Lanfax laboratories, Armidale.

Potarzycki, J., Gay, R., \& Schhnug, E. (2004). Phosphorus adsorption in soils after twenty years of organic (cattle slurry) and mineral (NPK) fertilization. Landbauforschung Volkenrode1, 54, 13-20.

Sanginga, N., Danso, S. K. A., Zapata, F., \& Bowen, G. D. (1995). Phosphorus requirements and nitrogen accumulation by $\mathrm{N}_{2}$ - fixing and non- $\mathrm{N}_{2}$ - fixing leguminous trees growing in low $\mathrm{P}$ soils. Biology and Fertility of Soils, 20, 205-211. http://dx.doi.org/10.1007/BF00336559

Sanginga, N., Lyasse, O., \& Singh, B. B. (2000). Phosphorus use efficiency and nitrogen balance of cowpea breeding lines in a low P soil of the derived savanna zone in West Africa. Plant and Soil, 220, 119-128. http://dx.doi.org/10.1023/A:1004785720047

Sims, J. T. (2000). A Phosphorus Sorption Index. Methods of phosphorus analysis for soils, sediments, residuals and water. In G. M. Pierzynski (Ed.), Southern Co-operative series Bulletin (No. 396, pp. 22-24). Kansas, USA. Retrieved from http://www.owrb.ok.gov/quality/standards/pdf_standards/scenicrivers/University\%20 of $\% 20$ Arkansas\%20Submittal.pdf

Smyth, A. J., \& Montgomery, R. F. (1962). Soils and Land Use in Central Western Nigeria (p. 265). Government Printers, Ibadan.

Udo, E. J., \& Ogunwale, J. A. (1986). Laboratory Manual for the Analysis of Soil, Plant and Water samples (2nd ed., p. 174). Imperial Binding Service.

Valizadeh, G. R., Rengel, Z., \& Rate, A. W. (2002). Wheat genotypes differ in growth and phosphorus uptake when supplied with different sources and rates of phosphorus banded or mixed in soil in pots. Australian Journal of Experimental Agriculture, 42, 1103-1111. http://dx.doi.org/10.1071/EA01087

Zhenoy, V. V., \& Kalagudi, G. M. (2005). Enhancing plant use efficiency for sustainable cropping. Biotechnology Advances, 23, 501-513. http://dx.doi.org/10.1016/j.biotechadv.2005.01.004

\section{Copyrights}

Copyright for this article is retained by the author(s), with first publication rights granted to the journal.

This is an open-access article distributed under the terms and conditions of the Creative Commons Attribution license (http://creativecommons.org/licenses/by/3.0/). 